\title{
Distribution and Movements of the Teshekpuk Caribou Herd 1990-2005: Prior to Oil and Gas Development
}

\author{
BRIAN T. PERSON, ${ }^{1,2}$ ALEX K. PRICHARD,${ }^{3}$ GEOFFRY M. CARROLL,${ }^{4}$ DAVID A. YOKEL,${ }^{5}$ ROBERT S. SUYDAM ${ }^{1}$ \\ and JOHN C. GEORGE ${ }^{1}$
}

(Received 18 July 2006; accepted in revised form 9 February 2007)

\begin{abstract}
Four caribou (Rangifer tarandus grantii) herds calve on the North Slope of Alaska, three of which have been exposed to little or no resource development. We present 15 years of baseline data on the distribution and movements of 72 satellite-collared and 10 GPS-collared caribou from the Teshekpuk caribou herd (TCH) that have had little to no exposure to oil and gas activities. Fixed-kernel home range analyses of collared caribou revealed that calving grounds were concentrated (i.e., $50 \%$ kernel utilization distribution) along the northeastern, eastern, and southeastern shores of Teshekpuk Lake. During the postcalving period, $51 \%$ and $35 \%$ of caribou moved through two constricted zones to the east and west of Teshekpuk Lake, respectively, and accessed insect-relief habitat along the Beaufort Sea coast. During late summer and early fall, TCH caribou were concentrated to the southeast and southwest of Teshekpuk Lake. Although 65\% of the Teshekpuk caribou wintered in two areas on the central coastal plain around the village of Atqasuk and south of Teshekpuk Lake, other TCH animals wintered in a great variety of places, including the Seward Peninsula, the eastern and southern Brooks Range, and the Arctic National Wildlife Refuge. We detected an apparent emigration rate of $6.9 \%$. One male and five female $\mathrm{TCH}$ caribou joined the breeding populations of the Western Arctic and Central Arctic herds. TCH caribou traveled an average distance of $2348 \pm 190 \mathrm{~km}$ annually. Movement rates were at a maximum in midsummer, lowest in winter, and intermediate during spring and fall migrations. Restrictions on oil and gas leasing and surface occupancy have been in place to protect calving, migratory corridors, and insect-relief habitat for the $\mathrm{TCH}$, but these protections are likely to be removed. These data will provide a good baseline that can be used to compare predevelopment distribution and movement patterns of $\mathrm{TCH}$ caribou to distribution and movement patterns during and after petroleum development.
\end{abstract}

Key words: Rangifer, satellite-collar, GPS, subsistence, emigration, Alaska, North Slope, National Petroleum Reserve-Alaska

RÉSUMÉ. Quatre hardes de caribous (Rangifer tarandus grantii) vêlent sur la côte nord de l'Alaska, dont trois de ces hardes ont été exposées à peu ou pas d'aménagement des ressources. Nous présentons des données de base échelonnées sur 15 ans relativement à la répartition et aux déplacements de 72 caribous dotés d'un collier émetteur par satellite et de 10 caribous munis d'un collier émetteur GPS de la harde de caribous de Teshekpuk (HCT), caribous qui ont été peu ou pas du tout frottés aux activités pétrolières et gazières. L'analyse du noyau fixe des domaines vitaux des caribous à collier a révélé que les lieux de vêlage étaient concentrés (c'est-à-dire 50 \% de la répartition de l'utilisation du noyau) le long des côtes nord-est, est et sud-est du lac Teshekpuk. Après la période de vêlage, 51 pour cent et 35 pour cent des caribous se déplaçaient au sein de deux zones de constriction à l'est et à l'ouest du lac Teshekpuk, respectivement, et accédaient un habitat où se trouvait moins d'insectes sur la côte de la mer de Beaufort. Vers la fin de l'été et le début de l'automne, les caribous de la HCT étaient concentrés au sud-est et au sud-ouest du lac Teshekpuk. Bien que 65 pour cent des caribous de Teshekpuk passaient l'hiver dans deux régions de la plaine côtière centrale autour du village d'Atqasuk et au sud du lac Teshekpuk, les autres bêtes de la HCT passaient l'hiver dans divers endroits, dont la péninsule de Seward, les versants est et sud des montagnes de Brooks et la Réserve faunique nationale de l'Arctique. Nous avons détecté un taux d'émigration apparent de 6,9 pour cent. Un caribou mâle et cinq caribous femelles de la HCT ont rejoint les populations de reproduction des hardes de l'ouest et du centre de l'Arctique. En moyenne, le caribou de la HCT parcourait une distance de $2348 \pm 190 \mathrm{~km}$ annuellement. Les taux de déplacement étaient à leur point le plus élevé au milieu de l'été, tandis qu'ils étaient à leur niveau le plus bas l'hiver et à un niveau intermédiaire pendant les migrations du printemps et de l'automne. Il existe des restrictions en matière de location et d'occupation en surface pour le pétrole et le gaz afin de protéger le vêlage, les corridors de migration et les habitats à faible taux d'insectes pour la HCT, mais il est vraisemblable que ces restrictions soient éliminées. Ces données fourniront une bonne base pour comparer la répartition et les déplacements du caribou de la HCT avant la mise en valeur des ressources à la répartition et aux déplacements du caribou de la HCT pendant et après la mise en valeur pétrolière.

\footnotetext{
${ }^{1}$ North Slope Borough Department of Wildlife Management, P.O. Box 69, Barrow, Alaska 99723, USA

${ }^{2}$ Corresponding author: Brian.Person@ north-slope.org

${ }^{3}$ ABR, Inc.-Environmental Research \& Services, P.O. Box 80410, Fairbanks, Alaska 99708-0410, USA

${ }^{4}$ Alaska Department of Fish and Game, P.O. Box 1284, Barrow, Alaska 99723, USA

${ }^{5}$ U.S. Bureau of Land Management, 1150 University Ave., Fairbanks, Alaska 99709, USA

(C) The Arctic Institute of North America
} 
Mots clés : Rangifer, collier émetteur par satellite, GPS, subsistance, émigration, Alaska, versant nord, réserve nationale de pétrole-Alaska

Traduit pour la revue Arctic par Nicole Giguère.

\section{INTRODUCTION}

Four herds of caribou (Rangifer tarandus grantii) calve throughout the North Slope of Alaska (i.e., the land north of the continental divide of the Brooks Range). Parturient caribou demonstrate fidelity to calving grounds, and Alaskan wildlife managers have used this behavior to assign an animal to a herd on the basis of its calving location (Skoog, 1968). The majority of animals in three of these herds - the Western Arctic herd (WAH), the Central Arctic herd (CAH), and the Porcupine caribou herd $(\mathrm{PCH})$ - winter south of the North Slope, while most of the Teshekpuk caribou herd (TCH) remains on the Arctic coastal plain (i.e., lands north of the continental divide with an elevation less than about 60 $\mathrm{m})$ throughout the winter. The TCH is an important subsistence resource, yet little has been published about this herd. Furthermore, oil and gas development is planned for portions of its range making it important to delineate the herd's range and behavior. We analyzed a long-term satellite telemetry dataset to determine seasonal herd distribution, herd fidelity, and rate of movement.

The seasonal ranges that caribou choose have life history consequences that are strongly influenced by their nutritional environment (Russell et al., 1993; Griffith et al., 2002; Cameron et al., 2005). Caribou maximize their nutritional intake through large-scale migratory movements to areas of higher habitat quality, changes in seasonal and annual distribution in response to changes in plant phenology and availability, and rapid movements to limit harassment by the mosquito (Culex spp.) and oestrid fly (Hypoderma spp. and Cephenemyia spp.). Caribou are generally thought to move to winter ranges where energyrich lichens are available, and they cope with this lowprotein diet by conserving and redistributing protein reserves and metabolites (Gerhart et al., 1996; Parker et al., 2005). It appears that calving is timed to occur in areas where vegetation has recently emerged after snowmelt. Vegetation is phenologically young at this time and has a low ratio of fiber to protein content, which supports both dam lactation and tissue deposition once rumen function develops in the offspring (Chapin et al., 1980; White, 1992; Griffith et al., 2002; Post et al., 2003; Knott et al., 2004). The ability of caribou to move freely among different seasonal ranges and within habitats during a season may be adversely affected by human activities, such as oil and gas development.

Until recently, oil and gas production on the North Slope of Alaska has been concentrated in a region between Prudhoe Bay and the Colville River that encompasses the calving grounds of the $\mathrm{CAH}$. Extensive $\mathrm{CAH}$ caribou monitoring and research has been carried out since the late 1970s, which has helped to improve mitigative measures. Interpretations of data collected to monitor the impacts on caribou of oil and gas development have been divergent (Cameron et al., 1992; Ballard et al., 2000; Cronin et al., 2000). During the 1980s, CAH calving occurred to the southwest, away from areas of development (Wolfe, 2000; Cameron et al., 2005). Much research throughout this period focused on negative multiplier effects (White, 1983) on the population resulting from the displacement of parturient cows to habitats that may be of lower nutritional quality than areas previously used by $\mathrm{CAH}$ cow-calf pairs (Wolfe, 2000; Cameron et al., 2005). Cronin et al. (2000) point out that the $\mathrm{CAH}$ population increased concurrently with oil and gas development and conclude that no population-level impacts from resource development have occurred. Demonstrating cause-and-effect relationships between resource extraction and wildlife populations is complicated by natural variation in caribou behavior, population trends, habitat selection, and climate. Detection of potential industrial impacts to the $\mathrm{CAH}$ has been further hampered by insufficient long-term distributional data collected prior to surface development.

There is federal and industrial interest in making the $\mathrm{TCH}$ calving grounds and summer and insect-relief areas available for oil and gas leasing (BLM, 1998, 2005). There is concern among the Inupiat, local land managers, and non-governmental organizations that increased industrial activity will reduce access to caribou as a subsistence resource by both lowering herd productivity and by displacement of caribou from traditional migratory routes and calving grounds. One unique aspect of the calving grounds around Teshekpuk Lake is two constricted (ca. $12 \mathrm{~km}$ ) landmasses through which caribou travel to insectrelief habitat, and it is likely that infrastructure will be placed in one or both of these areas. The TCH is an important subsistence resource; all villages on the North Slope have harvested caribou from this herd (Fuller and George, 1997; Prichard and Murphy, 2004). The TCH population has increased in the past decade despite estimated annual harvest levels between 5\% and 10\% (Fig. 1; Carroll, 2005). The fact that this herd has increased while supporting high harvest levels suggests high rates of reproduction and reproductive success, immigration from adjacent herds, or a combination of these factors.

Rangifer exhibit gregarious behavior, and fall and winter ranges of the different herds may overlap, particularly when herd populations are high. Under these circumstances, emigration has occurred in Rangifer systems (Ferguson et al., 2001; Finstad et al., 2002; Hinkes et al., 2005). The idea of interchange among herds of caribou calving on the North Slope is partially supported by a lack 


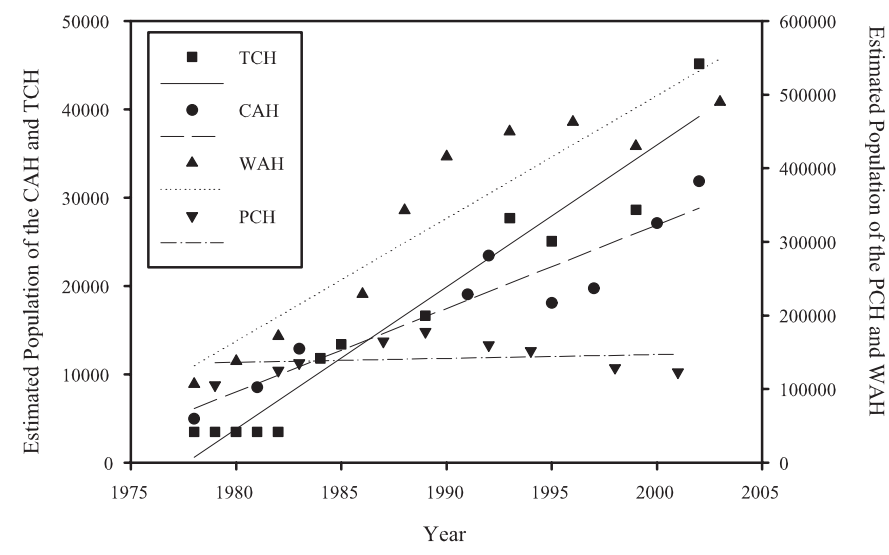

FIG. 1. Population estimates of the four caribou herds that calve on the North Slope of Alaska. $\mathrm{TCH}=$ Teshekpuk caribou herd; $\mathrm{CAH}=$ Central Arctic herd; $\mathrm{WAH}=$ Western Arctic herd; and $\mathrm{PCH}=$ Porcupine caribou herd. Data are from Carroll, 2005 (TCH); Lenart, 2005 (CAH); Dau, 2005 (WAH); and Stephenson, 2005 (PCH). of genetic distinctness found among those four herds (Cronin et al., 2003). Herd interchange has the potential to mask population effects of resource development and hunting at the herd level. Quantifying the rate of dispersal among herds would be useful to wildlife and land managers for assessing the concurrent impacts of harvest rate and increased industrial development on the North Slope.

We present a 15-year data baseline of TCH caribou movements and distribution. Data on 72 satellite-collared and 10 GPS-collared caribou were collected from 1990 to 2005, when little or no industrial infrastructure existed within their range (Fig. 2). Our objectives were to accomplish the following tasks prior to resource development within the annual range of the TCH: (1) determine calving, insect-relief, late summer, and winter home ranges of the TCH, (2) determine spring and fall migratory routes and the proportion of collared caribou moving through critical areas near Teshekpuk Lake, (3) describe rates of apparent emigration of collared $\mathrm{TCH}$

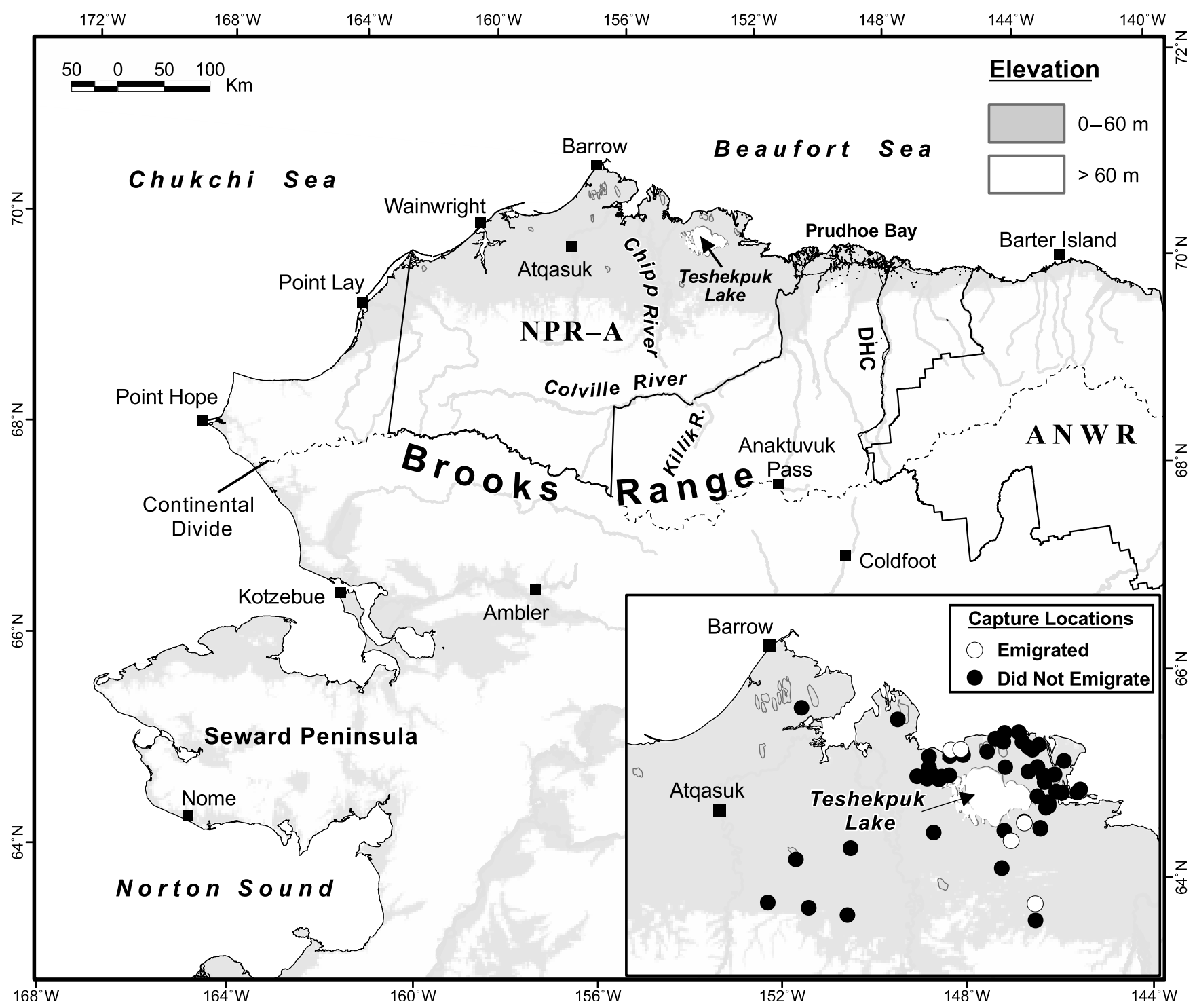

FIG. 2. A map of the study area throughout which caribou from the Teshekpuk caribou herd were distributed between 1990 and 2005 as measured by satellite and GPS collars. NPR-A = National Petroleum Reserve-Alaska, DHC = Dalton Highway Corridor, and ANWR = Arctic National Wildlife Refuge. We define the North Slope as all lands north of the continental divide. All lands less than ca. $60 \mathrm{~m}$ in elevation and north of the continental divide are considered to be the coastal plain. 
TABLE 1. Number of satellite-linked (PTT) and Global Positioning System-linked (GPS) telemetry collars deployed on caribou from the Teshekpuk caribou herd between 1990 and 2004. Y= year.

\begin{tabular}{|c|c|c|c|c|c|c|}
\hline Year & Deployment Date & Number Deployed & Female & Male & Collar Model ${ }^{1}$ & $\begin{array}{c}\text { PTT or GPS Duty Cycle } \\
\text { (hours) }\end{array}$ \\
\hline 1990 & July 1 & 6 & 6 & - & ST-3 & $\begin{array}{c}\text { Y1-Y2 } \\
1 \text { mo } 6 \text { on } 18 \text { off } \\
11 \text { mo } 6 \text { on } 42 \text { off }\end{array}$ \\
\hline 1991 & October 4 & 1 & 1 & - & ST-3 & $\begin{array}{c}\mathrm{Y} 1-\mathrm{Y} 2 \\
1 \mathrm{mo} 6 \text { on } 18 \text { off } \\
11 \text { mo } 6 \text { on } 42 \text { off }\end{array}$ \\
\hline 1992 & July 18 & 6 & 6 & - & ST-3 & $\begin{array}{l}\text { Y1 } 6 \text { on } 42 \text { off } \\
\text { Y2 } 6 \text { on } 42 \text { off }\end{array}$ \\
\hline 1993 & July 16 & 5 & 5 & - & ST-3 & $\begin{array}{l}\text { Y1 } 6 \text { on } 42 \text { off } \\
\text { Y2 } 6 \text { on } 42 \text { off }\end{array}$ \\
\hline 1994 & - & 0 & - & - & - & - \\
\hline 1995 & July $18-20$ & 7 & 7 & - & ST-3 & $\begin{array}{l}\text { Y1 } 6 \text { on } 42 \text { off } \\
\text { Y2 } 6 \text { on } 42 \text { off }\end{array}$ \\
\hline 1996 & - & 0 & - & - & - & - \\
\hline 1997 & July 4 & 2 & 1 & 1 & ST-3 & $\begin{array}{l}\text { Y1 } 6 \text { on } 42 \text { off } \\
\text { Y2 } 6 \text { on } 42 \text { off }\end{array}$ \\
\hline 1998 & July 29 & 2 & 2 & - & ST-3 & $\begin{array}{l}\text { Y1 } 6 \text { on } 42 \text { off } \\
\text { Y2 } 6 \text { on } 42 \text { off }\end{array}$ \\
\hline 1999 & - & 0 & - & - & - & - \\
\hline 2000 & July $8-9$ & 4 & 4 & & ST-18 A-3300 & $\begin{array}{l}\text { Y1 } 6 \text { on } 42 \text { off } \\
\text { Y2 } 6 \text { on } 138 \text { off } \\
\text { Y3 } 6 \text { on } 138 \text { off } \\
\text { Y4 } 6 \text { on } 42 \text { off }\end{array}$ \\
\hline 2001 & July $26-27$ & 11 & 5 & 6 & ST-18 A-3300 & $\begin{array}{l}\text { Y1 } 6 \text { on } 42 \text { off } \\
\text { Y2 } 6 \text { on } 42 \text { off } \\
\text { Y3 } 6 \text { on } 42 \text { off }\end{array}$ \\
\hline 2002 & September 8 & 8 & 5 & 3 & ST-18 A-3300 & $\begin{array}{l}\text { Y1 } 6 \text { on } 42 \text { off } \\
\text { Y2 } 6 \text { on } 42 \text { off } \\
\text { Y3 } 6 \text { on } 42 \text { off }\end{array}$ \\
\hline 2003 & June $25-26$ & 20 & 14 & 6 & ST-18 A-3300 & $\begin{array}{l}\text { Y1 } 6 \text { on } 42 \text { off } \\
\text { Y2 } 6 \text { on } 138 \text { off } \\
\text { Y3 } 6 \text { on } 42 \text { off }\end{array}$ \\
\hline 2004 & July $4-5$ & 10 & 10 & & TGW-3680 & Y1 18 on 6 off \\
\hline
\end{tabular}

${ }^{1}$ Telonics, Inc., Mesa, Arizona USA.

caribou to neighboring herds, and (4) estimate the distance traveled annually and seasonally based on GPS collar locations collected every three hours.

\section{METHODS}

\section{Caribou Capture and Calving Status}

In 1990 and 1991, we captured seven female caribou using a dart containing carfentanil and xylazine fired with a tranquilizer gun from a helicopter. Naloxone and yohimbine were used as antagonists to the tranquilizer. From 1992 to 2004, 75 caribou were captured, using either a skid-mounted net gun or one fired manually from a helicopter, and then blindfolded and restrained for collaring (Philo et al., 1993; Carroll, 2005). Caribou were typically captured in late June and July, and all caribou were fitted with a collar containing a conventional VHF radio-transmitter and either a satellite-linked (PTT) or a GPS-linked transmitter, with duty cycles that varied among years
(Table 1). Collars were adjusted to allow for growth and minimal rubbing, and expansion straps were attached to collars deployed on bulls to accommodate changes in neck girth during rut. We received location and mortality data from polar-orbiting satellites, transmitted through command and acquisition stations to ARGOS data processing centers (Fancy et al., 1988).

Aerial surveys were conducted annually to determine the calving status of female caribou in early to mid June (Carroll et al., 2005).

\section{Seasonal Distribution and Migratory Routes}

We divided each year into eight different seasons based on previously described caribou behavior (adapted from Russell et al., 1993): spring migration (16 April-31 May), calving (1-15 June), post-calving (16-30 June), mosquito harassment (1-15 July), mosquito and oestrid fly harassment (16 July - 7 August), late summer ( 8 August 15 September), fall migration and rut (16 September-30 November), and winter (1 December-15 April). 
We used Kernel Home Range (HR) (Seaman and Powell, 1996) to calculate kernel density distributions for calving, the period of maximum mosquito harassment, late summer, and winter. We selected one location nearest to the midpoint of each season from each individual caribou in each year in order to weight the distribution evenly because both the number of collars deployed and the duty cycles varied among years (Table 1). The distribution of calving locations was determined from the location as close as possible to peak calving (9 June) for all female caribou that successfully calved (Carroll, 2005). All caribou that emigrated (as defined below) from the TCH were removed from calculations of kernel density distributions.

Because of the linear nature of migratory movements we did not calculate a herd distribution kernel for spring and fall migration. In order to visually depict and quantify the distribution of migratory routes for collared caribou, we created a grid covering northern Alaska that consisted of $15 \mathrm{~km}^{2}$ cells. We determined the number of different caribou that migrated through each cell during each fall or spring season by connecting subsequent locations with straight lines. We did not include lines connecting locations more than seven days and $100 \mathrm{~km}$ apart because long gaps between locations were sometimes the result of intermittently functioning collars. We combined all years for all collared caribou to determine the total number of animals migrating through each grid cell during the study period.

The terrestrial corridors between Teshekpuk Lake and Smith Bay to the northwest and Kogru River to the east are relatively narrow (ca. $12 \mathrm{~km}$ ). It is probable that one or both of these corridors, which we will refer to as "constricted zones," will someday contain oil- and gas-related infrastructure that may obstruct caribou movements to and from the area north of the lake (BLM, 2005). We calculated the proportion of collared caribou that moved through the Smith Bay and Kogru River constricted zones using methods similar to those of Prichard et al. (2003). We determined the number of collared caribou in each of these zones, as well as the total number of collars transmitting in each two-week time period. We removed all locations within 30 days of the date when a caribou was collared because many of these animals were captured near these zones. We included only those animals that had six locations within each time period to ensure that we had a good record of an animal's movement for that period.

\section{Apparent Emigration}

We define apparent emigrants from the $\mathrm{TCH}$ as those individuals that were collared within $50 \mathrm{~km}$ of Teshekpuk Lake during June and July and were observed near the calving grounds of the WAH or CAH in subsequent years during the calving season. However, we also included among the emigrants two animals collared in September 2002 because both of these animals calved with the TCH in 2003 and were subsequently observed with the CAH at calving in 2004. We qualify the term "emigration" with the word "apparent" because we assume that our collared caribou were born on the calving grounds around Teshekpuk Lake. We determined the proportion of caribou that met our criteria for apparent emigration and tested for differences in apparent emigration between male and female caribou using a chi square test. Differences were considered to be statistically significant at $\alpha \leq 0.05$.

\section{Distance Traveled}

We calculated the distance traveled by 10 females fitted with GPS collars (programmed to collect locations every three hours) by calculating the distance $(\mathrm{km})$ and rate of travel $(\mathrm{km} / \mathrm{h})$ between each successive pair of locations. Although $95.4 \%$ of caribou days had eight locations per day, there were 163 caribou-days with fewer than eight locations and six caribou-days with no locations. To correct for days that had fewer than eight locations, we calculated the mean rate of travel for each day. For the six caribou-days for which we had no rate-of-travel information, we used calculated averages of the rate of travel on the previous and subsequent days. We calculated the total distance traveled in a year by GPS-collared caribou by summing the linear distances between each successive pair of locations. We tested for seasonal differences in movement rates using an analysis of variance (ANOVA). If the overall model showed significant differences at $p \leq 0.05$, we then tested for differences among seasons using Tukey's multiple comparison method. We also compared the rate traveled by caribou that wintered on the central coastal plain to that of animals that wintered along the western coast of the Chukchi Sea or in the eastern Brooks Range using paired t-tests and evaluated these results to a Bonferroni-corrected level of significance at $\alpha \leq 0.00625$. Data presented in the text represent the mean \pm 1 standard error of the mean (SE). All analyses were performed using SPSS 14.0 statistical software (SPSS Inc., 2005).

\section{RESULTS}

\section{Seasonal Distribution and Migratory Routes}

Kernel distribution analyses of collared TCH caribou locations during calving in 1990-2005 revealed that the $50 \%$ kernel utilization encompassed the area immediately southeast, east, and north of Teshekpuk Lake, while the 99\% utilization distribution covered the area around Teshekpuk Lake between the Chipp River to the west and Harrison Bay to the east (Fig. 3a). Utilization distributions for successful cows during calving encompassed an area of $1380 \mathrm{~km}^{2}$ for $50 \%$ and $7201 \mathrm{~km}^{2}$ for $90 \%$ of the utilization distribution. During the post-calving period, 16-30 June, animals generally began to move farther to the north of Teshekpuk Lake and the utilization distribution increased to $2411 \mathrm{~km}^{2}$ for $50 \%$ and $18313 \mathrm{~km}^{2}$ for $99 \%$ of the utilization distribution. Mosquitoes typically begin to 

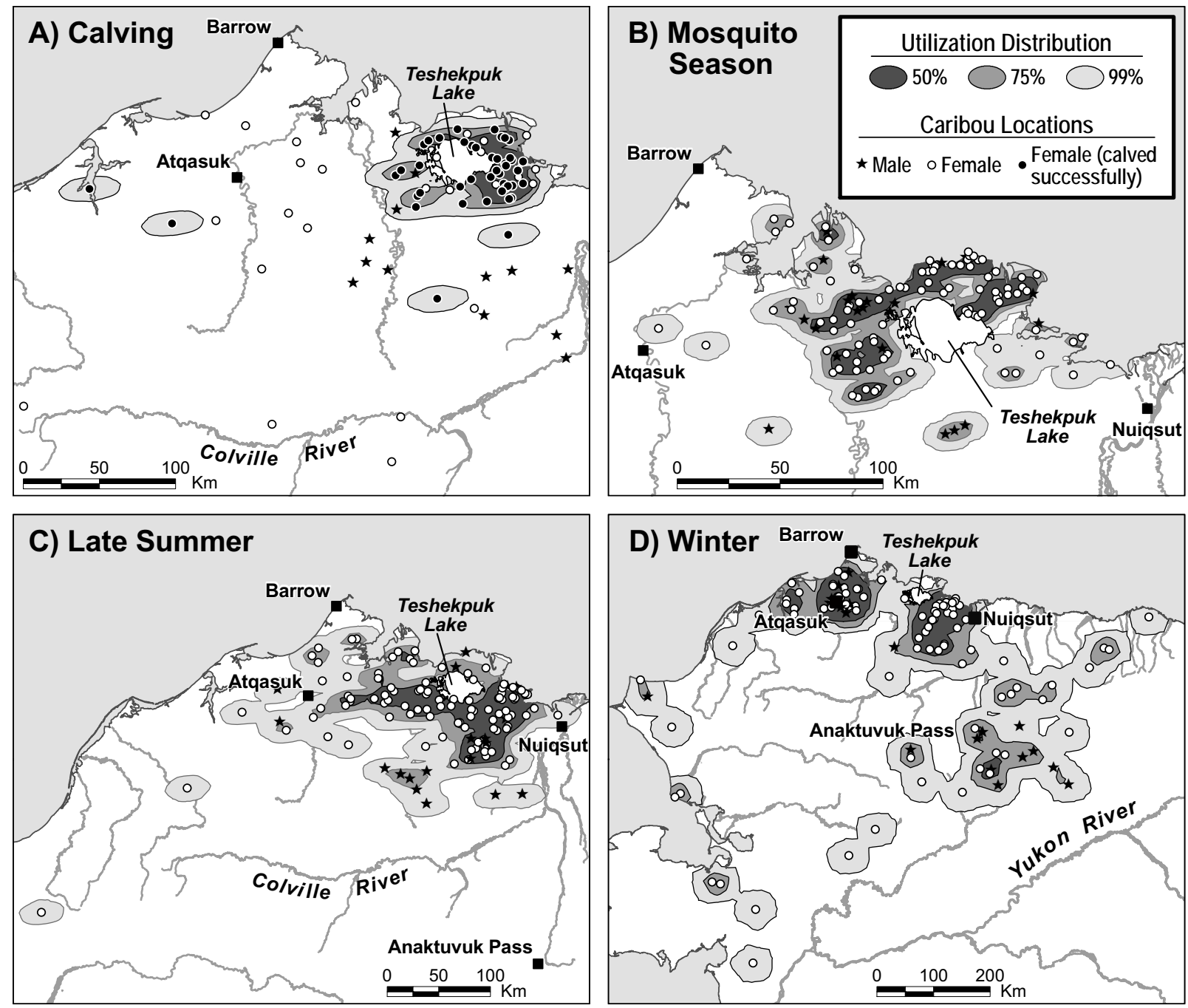

FIG. 3. Kernel utilization distribution (50\%, 75\%, and 99\%) of caribou from the TCH as measured by satellite and GPS collars between 1990 and 2005 . Figure panels represent: A) the calving season (1-15 June), B) mosquito harassment season (1-15 July), C) late summer (8 August-15 September) and, D) the winter season (1 December-15 April).

emerge in early July, at which time caribou further expanded their distribution to the north and west of Teshekpuk Lake (Fig. 3b). The 50\% utilization distribution for the mosquito season encompassed an area of $1748 \mathrm{~km}^{2}$ and the $99 \%$ utilization distribution was $8560 \mathrm{~km}^{2}$ between 1 July and 15 July. During the mosquito and oestrid fly season, 16 July -7 August, TCH range increased to $5458 \mathrm{~km}^{2}$ for $50 \%$ of the utilization distribution and $26429 \mathrm{~km}^{2}$ for $99 \%$ of the distribution. During late summer and early fall, $50 \%$ of the utilization distribution was centered to the southwest, south, and southeast of Teshekpuk Lake, and this distribution encompassed a $50 \%$ range of $5662 \mathrm{~km}^{2}$ (Fig. 3c). The 99\% range of collared caribou during late summer was $31996 \mathrm{~km}^{2}$, which encompassed Atqasuk and was centered approximately $30 \mathrm{~km}$ south of Barrow. Analyses revealed two concentrated (i.e., $50 \%$ kernel utilization distribution) wintering areas on the central coastal plain, one to the west, centered on Atqasuk and one southeast of Teshekpuk Lake (Fig. 3d). The distribution of wintering caribou was variable among years. During the winters of 1990 to 2005,
$65 \%$ of collared $\mathrm{TCH}$ caribou wintered in the two regions of the central coastal plain mentioned above, $21 \%$ in the central and eastern Brooks Range, $11 \%$ along the coast of the Chukchi Sea from Barrow south to the Seward Peninsula, and 3\% in the Arctic National Wildlife Refuge (ANWR). The 50\% utilization distribution of concentrated wintering areas encompassed $16903 \mathrm{~km}^{2}$ and the 99\% distribution encompassed $153711 \mathrm{~km}^{2}$.

A total of 119 routes were used to delineate fall migration corridors. Fall migratory routes are most pronounced between the Teshekpuk Lake area and Atqasuk (Fig. 4a). Another conspicuous route extends to the west along the Chukchi Sea coast past the villages of Wainwright, Point Lay, and Point Hope. Several groups of two to four animals moved along routes that pass through contiguous grid cells. One route extends south of the central coastal plain through the Killik River drainage and continued south of the Brooks Range past Ambler to Norton Sound, and another route goes south of the coastal plain and parallels the Dalton Highway Corridor (DHC), which is used to 

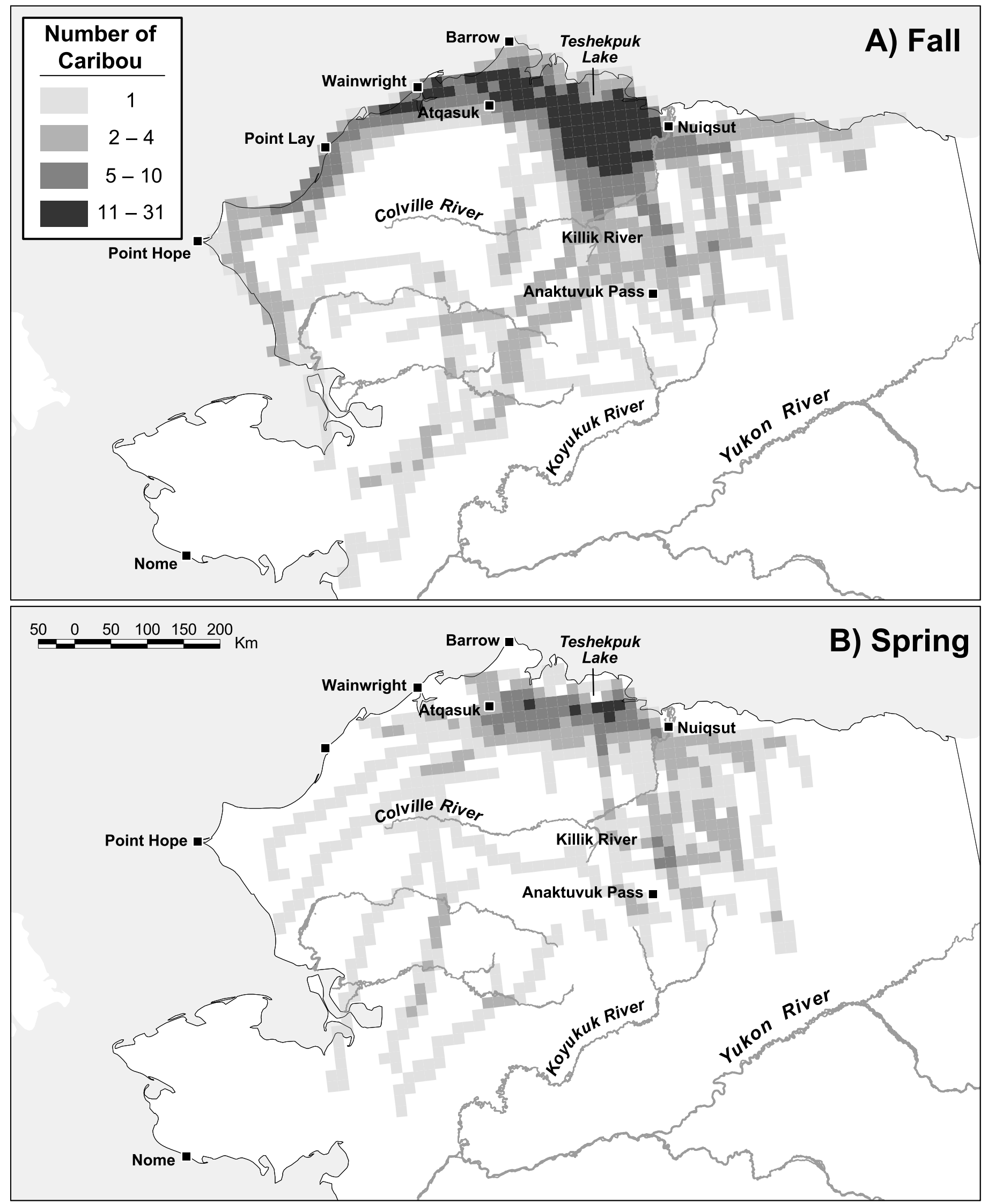

FIG. 4. Migratory routes of TCH caribou as measured by satellite and GPS collars between 1990 and 2005 for A) the fall migration and rutting period 16 September30 November) and B) the spring migration (16 April-31 May). 


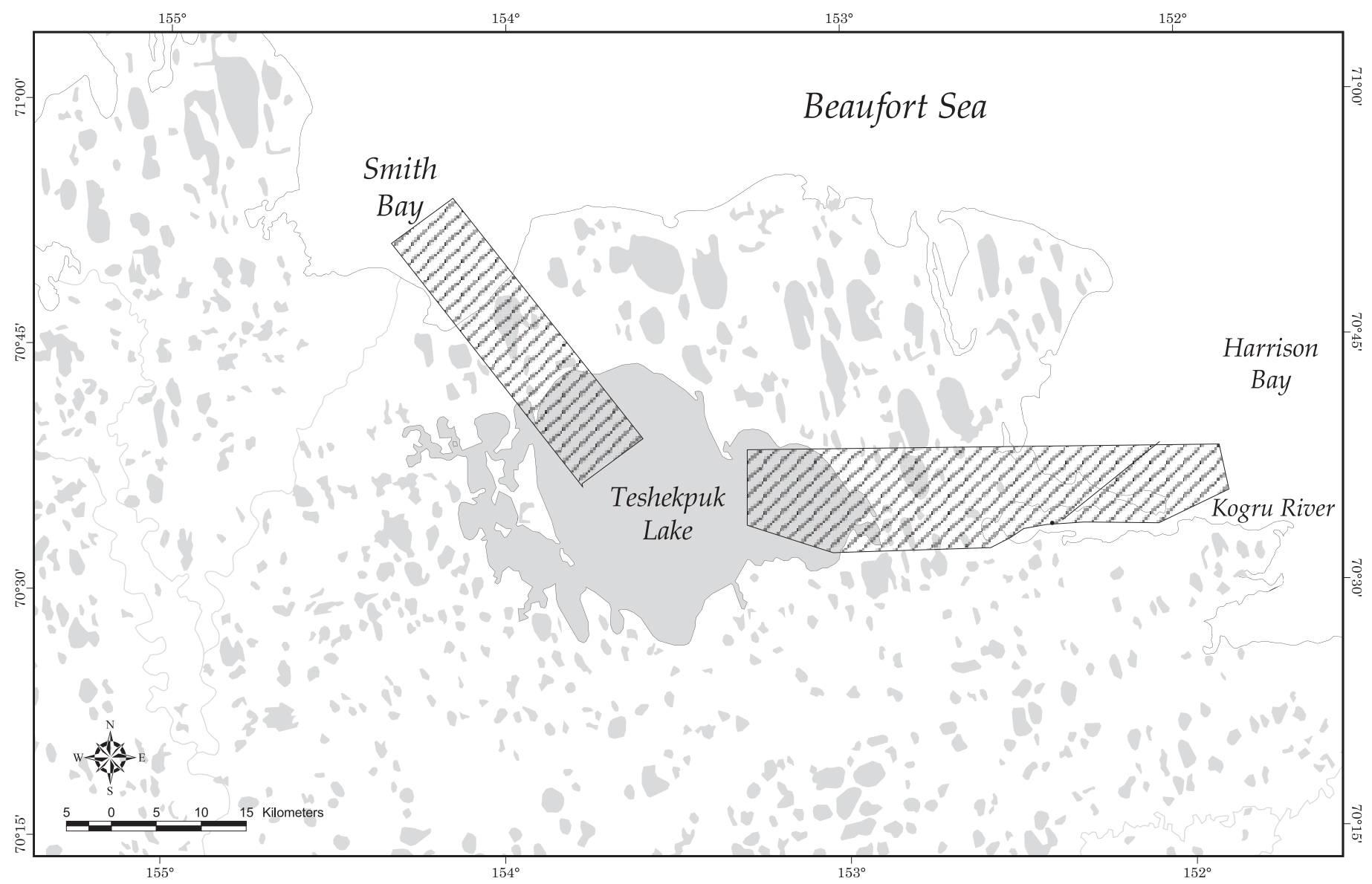

FIG. 5. Map of constricted areas to the east and west of Teshekpuk Lake through which TCH caribou travel to reach insect-relief habitat along the Beaufort Sea coast.

access wintering areas in the central Brooks Range. Another minor route extends from the central coastal plain along the northern coast of the Beaufort Sea and was established when a substantial portion of the herd migrated to the Arctic National Wildlife Refuge during the winter of 2003-04 (Fig. 4a).

Spring migratory routes are based on 87 spring migration events determined by PTT- and GPS-collared caribou between 1990 and 2005. The route used by the highest density of collared caribou in May is between Atqasuk and the southern shores of Teshekpuk Lake. Other spring routes reflect those used during the fall migration along the DHC, south of the western and central Brooks Range, and along the coasts of the Chukchi and Beaufort seas (Fig. 4b).

Between mid May and August, a high proportion of collared caribou were observed in either or both of the constricted zones around Teshekpuk Lake (Fig. 5). When averaged for the 15 years of this study, the proportion of caribou using the area to the east, between the lake and the Kogru River, peaked on 1 July at $51 \% \pm 6.8 \%$ of all collared caribou (Fig. 6). Use of the constricted zone to the west of Teshekpuk Lake peaked during the second week of July at $35 \% \pm 6.9 \%$ of all collared caribou in the area. Later, in the first week of October, $14 \% \pm 3.5 \%$ of the collared caribou used the Kogru corridor.

\section{Apparent Emigration}

Fifty-six collared TCH caribou met our criteria for estimating apparent emigration. Of this sample, the average number of years that collars were active, or that caribou survived, was 1.55 (range $1-4$ years). Six collared caribou, one male and five females, emigrated from the $\mathrm{TCH}$ to the WAH and CAH over the course of 87 collar years (Table 2). This represents an overall apparent emigration rate of $0.069 \pm 0.027$ of TCH caribou per year. The apparent emigration rate of males was $0.071 \pm 0.069$ of 14 caribou years, and the single emigrant male joined the $\mathrm{CAH}$. The female apparent emigration rate was $0.068 \pm$ 0.03 of 73 caribou years. Three emigrant females joined the $\mathrm{CAH}$, while the other two joined the WAH. The rate of apparent emigration to the $\mathrm{CAH}$ and WAH was equal, $0.034 \pm 0.019$ throughout 87 caribou years. We found no difference in rates of apparent emigration between males and females (chi-square $=0.02, \mathrm{df}=1 ; p=0.968$ ).

\section{Distance Traveled}

GPS-collared female TCH caribou traveled an average distance of $2348.0 \pm 190.5 \mathrm{~km}$ throughout the year, and their rate of travel varied among seasons $(F=43.68, \mathrm{df}=7$; 


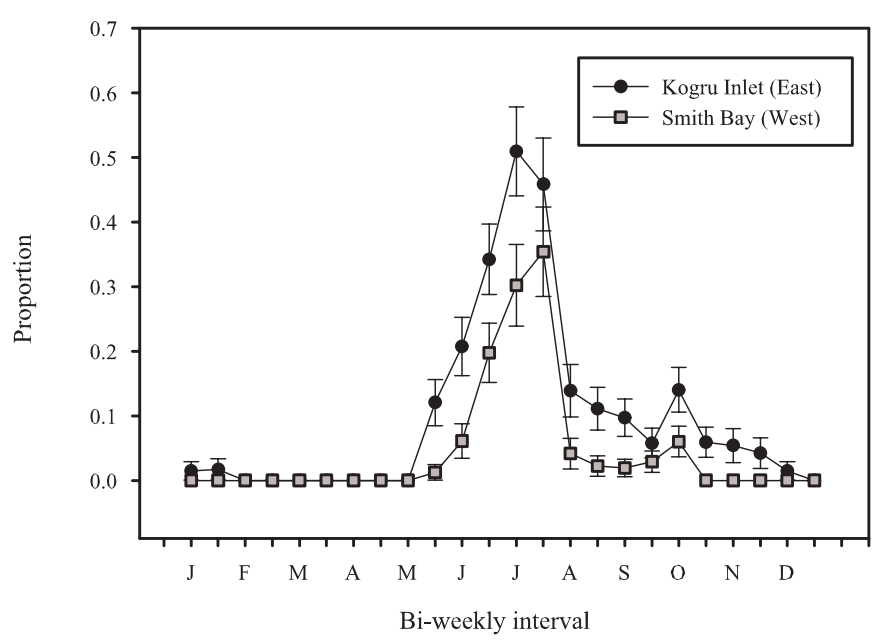

FIG. 6. Proportion of satellite- and GPS-collared caribou moving through constricted areas to the east and west of Teshekpuk Lake between 1990 and 2005.

$p<0.001$ ) (Table 3). Caribou traveled over $18 \mathrm{~km}$ per day during the mosquito and oestrid fly seasons between 1 July and 7 August (Fig. 7). In contrast, they traveled an average distance of $2.8 \mathrm{~km}$ per day during the winter season. Throughout the rest of the year, caribou traveled an average distance of between 6.4 and $7.5 \mathrm{~km}$ per day (Table 3 ).

Animals that wintered on the central coastal plain consistently traveled shorter distances throughout the year than animals that wintered elsewhere, though the difference was not statistically significant (Fig. 7). The four animals that remained on the coastal plain during the winter traveled $1766 \pm 113 \mathrm{~km}$ per year compared to 2736 $\pm 169 \mathrm{~km}$ per year traveled by the six caribou that wintered off the central coastal plain. After Bonferroni corrections, we found no differences in the seasonal rate of travel between animals that wintered on or off the central coastal plain except during the spring $(\mathrm{t}=7.726, \mathrm{df}=6.08 ; p=$ 0.0002 ), when caribou that wintered off the central coastal plain traveled $8.4 \pm 0.7 \mathrm{~km} \mathrm{~d}^{-1}$ compared to $3.6 \pm 0.3 \mathrm{~km} \mathrm{~d}^{-1}$ for animals that wintered near Teshekpuk Lake.
TABLE 2. Proportion of Teshekpuk caribou herd (TCH) caribou emigrating to either the Central Arctic herd (CAH) or the Western Arctic herd (WAH) between 1990 and 2005, as measured by satellite and GPS telemetry.

\begin{tabular}{lcccc}
\hline \hline & $\begin{array}{c}\text { Number } \\
\text { emigrated }\end{array}$ & $\begin{array}{c}\text { Number } \\
\text { of collar years }\end{array}$ & $\begin{array}{c}\text { Proportion } \\
\text { emigrated }\end{array}$ & Standard Error \\
\hline Overall & 6 & 87 & 0.069 & \pm 0.027 \\
CAH & 4 & 87 & 0.046 & \pm 0.022 \\
WAH & 2 & 87 & 0.023 & \pm 0.016 \\
Males & 1 & 14 & 0.071 & \pm 0.069 \\
Females & 5 & 73 & 0.068 & \pm 0.030 \\
\hline \hline
\end{tabular}

\section{DISCUSSION}

\section{Seasonal Distribution and Migratory Routes}

We sought to better understand the movements and distribution of the TCH when we initiated this project in 1990 because we recognized that industrial development would ultimately encroach upon its range. We recognize that our sampling effort varied; nonetheless, we believe that the data presented constitute a conservative baseline to which we can compare the future distribution and movements of TCH caribou throughout their winter, calving, insect-relief, and post-calving ranges that coincide with oil and gas development (BLM, 2005).

Caribou calving grounds may shift gradually over the years or may change abruptly because of poor environmental conditions during migration (Fleck and Gunn, 1982; Valkenburg and Davis, 1986; Gunn, 2000; Hinkes et al., 2005). Caribou from the TCH were reported to calve west and south of Teshekpuk Lake prior to 1978, and east, northeast, and north of the lake in the 1980s (Davis and Valkenburg, 1979; Reynolds, 1982; Silva, 1985; Carroll, 1992). Calving ground surveys in 1991 and 1992 indicated that most calving occurred to the northeast and east of Teshekpuk Lake (Carroll, 1993). Our analyses revealed that $92 \%$ of collared caribou demonstrate fidelity to the calving grounds near Teshekpuk Lake. Fifty percent of all collared caribou were concentrated within the northeastern, eastern, and southeastern portion of the Teshekpuk

TABLE 3. Distance traveled by caribou from the Teshekpuk caribou herd as measured by 10 GPS collars. Distances traveled varied among seasons $(\mathrm{F}=43.68, \mathrm{df}=7 ; p<0.001)$. Seasons with shared letters are not statistically different at $\alpha \leq 0.05$ (Tukey's Multiple comparison).

\begin{tabular}{|c|c|c|c|c|c|c|c|c|c|}
\hline & \multirow[b]{2}{*}{$\begin{array}{l}\text { Total Distance } \\
\text { Traveled }(\mathrm{km})\end{array}$} & \multicolumn{8}{|c|}{$\begin{array}{l}\text { Average Distance traveled } \mathrm{km} \mathrm{d}^{-1} \\
\text { Season }\end{array}$} \\
\hline & & $\begin{array}{l}\text { Spring } \\
\text { Migration }\end{array}$ & Calving & Post-calving & Mosquito & Oestrid fly & $\begin{array}{l}\text { Late } \\
\text { Summer }\end{array}$ & $\begin{array}{c}\text { Fall } \\
\text { Migration }\end{array}$ & Winter \\
\hline Tukey's & & $\mathrm{AB}$ & A & A & $\mathrm{C}$ & $\mathrm{C}$ & $\mathrm{AB}$ & A & B \\
\hline Mean & 2348.1 & 6.47 & 7.53 & 6.80 & 18.54 & 18.64 & 6.63 & 7.10 & 2.83 \\
\hline SE & \pm 190.46 & \pm 0.89 & \pm 0.94 & \pm 0.32 & \pm 1.46 & \pm 1.32 & \pm 0.28 & \pm 0.98 & \pm 0.31 \\
\hline
\end{tabular}

${ }^{1}$ Seasons are adapted from Russell et al. (1993): spring migration (16 April-31 May), calving (1 - 15 June), post-calving (16-30 June), mosquito harassment ( $1-15$ July), mosquito and oestrid fly harassment (16 July - 7 August), late summer (8 August - 15 September), fall migration and rut (16 September-30 November) and winter (1 December-15 April). 


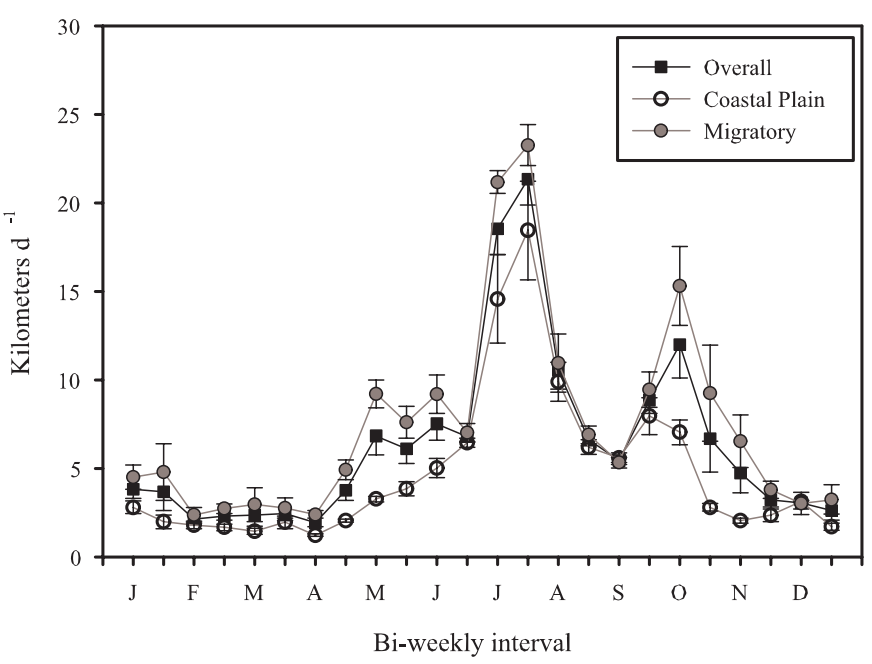

FIG. 7. Rates of travel of GPS-collared female caribou $(\mathrm{n}=10)$ between 1 July 2004 and 30 June 2005. "Migratory" refers to animals that wintered off the central coastal plain of Alaska, either along the northwestern coast of the Chukchi Sea or within and south of the eastern Brooks Range.

Lake region during the calving season. Our estimates of the $99 \%$ kernel utilization distribution of calving grounds are similar to those reported by Griffith et al. (2002), who found that the average $99 \%$ kernel distribution of $\mathrm{PCH}$ calving grounds was $7604 \mathrm{~km}^{2}$ (compared to our estimate of $7201 \mathrm{~km}^{2}$ for successfully calving cows). We did not statistically compare annual variation in the concentrated calving distribution because we had fewer than five active collars in the 1991, 1994, and 1996-99 calving seasons. Our data on TCH caribou calving distribution concur with those of Carroll et al. (2005); however, they were able to examine each year separately and concluded that in years with early snowmelt, the distribution of caribou at calving is shifted to the north of Teshekpuk Lake.

Parturient caribou reach the calving grounds soon before vegetation green-up, a time that coincides with minimal disturbance from hunting (Prichard et al., 2003; Carroll, 2005). Throughout this study's time frame, industrial and human disturbance to calving caribou has been minimal because of land-use allocations adopted by federal land managers and cultural practices of the Inupiat who inhabit this region (BLM, 1998; Carroll et al., 2005). If the area is made available for oil and gas leasing, cows and calves could be displaced from summer and insect-relief habitat along the Beaufort Sea coast (BLM, 2005). To reach the coast, $86 \%$ of the collared caribou moved through the Kogru Inlet and Smith Bay corridors within two weeks of calving, which typically peaks around 9 June (Carroll, 2005). Roads and pipelines in the oil fields that overlay the $\mathrm{CAH}$ calving grounds displace cows with calves by $2-4 \mathrm{~km}$ for two weeks after calving (Cameron et al., 1992; Nellemann and Cameron, 1998). Displacement from preferred habitat at this time of year could jeopardize calf survival and recruitment because the intake of milk by nursing calves is proportional to the nitrogen and energy intake of lactating caribou (Chan-McLeod et al., 1999).
The majority of the TCH has consistently overwintered on the central coastal plain near Atqasuk and southeast of Teshekpuk Lake, but some animals demonstrated remarkable variation in locations used for wintering (Prichard and Murphy, 2004). For the past five to seven years, some TCH caribou have wintered south of the Brooks Range near Coldfoot, and in the winter of 2003-04, groups of $\mathrm{TCH}$ animals overwintered in the foothills of the ANWR and on Barter Island. It is unclear what factors determine the choice of wintering areas in this herd, but it is likely related to the late summer range overlap with the WAH and $\mathrm{CAH}$, weather-related factors, predators, or availability of forage, which is affected by fall icing events on the North Slope. Given that caribou may abruptly change their calving locations from year to year for environmental reasons, it seems reasonable that wintering areas could change for similar reasons (Gunn and Miller, 1986).

The TCH is unique when compared to the other three herds that calve along the North Slope, in that it is the only herd in which over $50 \%$ of the population typically overwinters on the coastal plain. Hence, the villages of Atqasuk, Barrow, and Nuiqsut rely heavily on this herd for a source of protein in winter (Brower and Opie, 1997; Prichard et al., 2003). The annual variation of winter ranges enables the harvest of TCH caribou by all eight North Slope villages and the southern villages of Ambler and Coldfoot. The herd's variable winter distribution and the fact that villages may harvest caribou from several herds complicate the task of estimating harvest levels for the TCH. However, our baseline data, coupled with data from harvest monitoring projects, have proven to be useful for that purpose (Prichard et al., 2003). Between 5\% and $10 \%$ of the herd is harvested annually by subsistence users throughout its range (Carroll, 2005). Sport harvest of this herd has been low partly because of its inaccessibility to hunters from urban centers in Alaska and partly because of hunting and off-road vehicle regulations that currently protect the $\mathrm{TCH}$ and $\mathrm{CAH}$ as they migrate along the DHC.

\section{Apparent Emigration}

We calculated that $6.9 \%$ of collared $\mathrm{TCH}$ caribou apparently emigrated to either the WAH or CAH over the course of our study (Table 2). Four of the six caribou that apparently emigrated from the $\mathrm{TCH}$ joined the breeding population of the CAH. Of these, three animals, including one bull, had overwintered in the ANWR and the eastern Brooks Range in 2003-04. The collared caribou would indicate that during most years there is little emigration, but that during one year (2003-04) a relatively large percentage of the collared caribou (and possibly thousands of other TCH caribou) apparently emigrated to the CAH. Such events could explain some of the interannual variance in the population estimates presented in Figure 1. Our estimates of apparent emigration represent acute events, while the genetic data represent an integrated representation of nuclear and maternal gene flow among these 
subpopulations that occurred throughout a few to many generations. A more complete understanding of the periodicity of apparent emigration events is necessary to draw inferences about the population dynamics of the WAH, $\mathrm{TCH}$, and $\mathrm{CAH}$. Understanding rates of interchange between herds is of particular importance because immigration events may prevent detection of potential impacts from oil and gas development to the $\mathrm{CAH}$ population $-\mathrm{a}$ subject that remains controversial (Cameron et al., 1992; Nellemann and Cameron, 1998; Cronin et al., 2000).

\section{Distance Traveled}

The annual distances traveled by the TCH are considerably shorter than those reported for the $\mathrm{PCH}$ and $\mathrm{CAH}$; Fancy et al. (1989) reported a mean annual distance traveled of $4355 \mathrm{~km}$ for the $\mathrm{PCH}$ and $3031 \mathrm{~km}$ for the $\mathrm{CAH}$, whereas TCH caribou traveled an average of $2348 \pm 190 \mathrm{~km}$ annually. Although the actual movement rate values vary among herds, the pattern of movements is similar for all three herds. Movement rates were at a maximum in midsummer, lowest in winter, and intermediate during spring and fall migrations. Results from the $\mathrm{TCH}$ differ from those of Fancy et al. (1989) in that they show a more prolonged period of minimal movement in winter than do the PCH and CAH caribou. These differences are due in part to the fact that TCH caribou tend to winter on or nearby their concentrated late summer range. Previous studies of these data indicated that the distance traveled by collared caribou varied substantially among years, but consistently was highest in July, somewhat lower during spring and fall migration, and lowest in winter (Prichard and Murphy, 2004). There was a slight decrease in overall distance traveled during early to mid June, indicating that cows with newborn calves were relatively sedentary immediately after calving. Distance traveled calculations suggest that insect harassment has a strong effect on the TCH. Distance traveled peaked in mid July, when both oestrid flies and mosquitoes typically are active. Because insect harassment is strongly tied to temperature levels (Dau, 1986; Nixon, 1991; Mörschel and Klein, 1997; Mörschel, 1999), summer temperature should greatly affect the energy budget of TCH caribou. In contrast, distance traveled calculations show that the late summer period is one of little activity, when caribou put on weight and amass protein reserves for the winter (Cameron et al., 1991; Griffith et al., 2002).

Females that wintered on the central coastal plain traveled an average daily distance of $4.8 \pm 0.9 \mathrm{~km} \mathrm{~d}^{-1}$ compared to an average daily distance of $7.5 \pm 1.1 \mathrm{~km}$ for females that migrated off the Arctic coastal plain in the fall. Three of the four cows that overwintered on the coastal plain had calves associated with them the following spring, and so did four of the six cows that overwintered elsewhere. We find it interesting that the disparity in travel rates between these two groups of animals was observed throughout the year. Even during the insect harassment and rutting seasons, animals that wintered on the coastal plain had lower rates of travel. Several authors (Schaefer et al., 2000; Hinkes et al., 2005) have described similar behavior and attributed those differences to ecotypic variation within herds. We are not comfortable attributing the differences that we have observed to ecotypic variation because we describe movement rates for only 10 females from one calendar year. The differences that we observed may be more simply accounted for by variation in agespecific experience or body condition, or both.

\section{CONCLUSIONS}

The TCH demonstrates a high degree of fidelity to its calving grounds, with $92 \%$ of collared females using the area around Teshekpuk Lake during the first two weeks of June. Among the satellite-collared and GPS-collared animals, $51 \%$ used the narrow eastern corridor and $35 \%$ used the western corridor around the lake to access insect-relief areas between 1990 and 2005. Additionally, 65\% of collared TCH caribou overwintered on the central coastal plain, which is unique when compared to the other three herds, which typically winter south of the North Slope of Alaska or in Canada. Previous federal administrations protected crucial calving and insect-relief areas with restrictions on occupancy and building of surface structures, but these mitigative measures are likely to be removed (BLM, 2005). We suggest that land managers proceed with caution when permitting development and exploration in the TCH range for several reasons: 1) This herd has not been exposed to oil and gas development; 2 ) about $65 \%$ of the herd will be in contact with oil and gas development during all seasons; 3 ) the result of displacing $\mathrm{TCH}$ caribou from calving and insect-relief areas is not understood; 4) it would be difficult to mitigate disruption within the migration corridors to the east and west of Teshekpuk Lake; and 5) displacement of TCH caribou could reduce the number of animals available to North Slope hunters, affecting the food supply of their communities.

Our data will prove useful in documenting potential changes in caribou distribution and behavior within the annual range of TCH caribou, as well as in helping mitigate potential negative impacts of resource development. A better understanding of immigration and emigration rates among the herds that calve on the North Slope would allow more effective management for all four herds and improve our understanding of the potential effects of resource development on these herds.

\section{ACKNOWLEDGEMENTS}

This project would not have been possible without the support and funding provided by the North Slope Borough, the State of Alaska Department of Fish and Game, the Bureau of Land Management, and grants received from the Alaska Department of Commerce, 
Community and Economic Development (formerly the Alaska Department of Community and Economic Development). We are particularly grateful to M. Webb, R. Swisher, J. Larrivee, and the North Slope Borough Department of Search and Rescue for their excellent piloting skills. We appreciate the field assistance provided by M. New, T. O'Hara, L. Parrett, M. Keech, H. Brower, and T. Hepa. We credit Mike Philo, formerly of the North Slope Borough Department of Wildlife Management, for his foresight in initiating this satellite telemetry project in 1990. We also thank A. Zusi-Cobb, who made the GIS figures. This manuscript benefited from comments provided by $\mathrm{M}$. Cronin and two anonymous reviewers.

\section{REFERENCES}

BALLARD, W.B., CRONIN, M.A., and WHITLAW, H.A. 2000. Caribou. In: Truett, J.C., and Johnson, S.R., eds. The natural history of an Arctic oil field: Development and the biota. San Diego: Academic Press. 85-104.

BLM (BUREAU OF LAND MANAGEMENT). 1998. Northeast National Petroleum Reserve-Alaska: Final integrated activity plan/environmental impact statement. Vol. 2. Available from the BLM Alaska State Office, 222 West 7th Avenue, Anchorage, Alaska 99513.

- - - 2005. Northeast National Petroleum Reserve-Alaska: Final amended integrated activity plan/environmental impact statement. Vol. 1. Available from the BLM Alaska State Office, 222 West 7th Avenue, Anchorage, Alaska 99513.

BROWER, H.K., and OPIE, R.T. 1997. North Slope Borough subsistence harvest documentation project: Data for Atqasuk, Alaska for the period July 1, 1994 to June 30, 1995. Available from the Department of Wildlife Management, North Slope Borough, Box 69, Barrow, Alaska 99723.

CAMERON, R.D., SMITH, W.T., and FANCY, S.G. 1991. Comparative body weights of pregnant/lactating and nonpregnant female caribou. In: Butler, C.E., and Mahoney, S.P., eds. Proceeding of the Fourth North American Reindeer and Caribou Symposium. St. Johns: Newfoundland Labrador Wildlife Division. 109-114.

CAMERON, R.D., REED, D.J., DAU, J.R., and SMITH, W.T. 1992. Redistribution of calving caribou in response to oil field development on the Arctic Slope of Alaska. Arctic 45(4): $338-342$.

CAMERON, R.D., SMITH, W.T., WHITE, R.G., and GRIFFITH, B. 2005. Central Arctic caribou and petroleum development: Distributional, nutritional, and reproductive implications. Arctic 58(1):1-9.

CARROLL, G.M. 1992. Caribou survey-inventory progress report, Unit 26A. In: Abbott, S.M., ed. Alaska Department of Fish and Game, Division of Wildlife Conservation, Federal Aid in Wildlife Restoration Survey-Inventory Management Report, 1 July 198930 June 1991. Caribou. Project W-23-3, W-23-4, Study 3.0. Juneau: Alaska Department of Fish and Game. 177-186.

- - - 1993. Caribou survey-inventory progress report, Unit 26A. In: Abbott, S.M., ed. Alaska Department of Fish and Game, Division of Wildlife Conservation, Federal Aid in Wildlife Restoration Survey-Inventory Management Report, 1 July 1990 -
30 June 1992. Caribou. Project W-23-5, W-24-1, Study 3.0. Juneau: Alaska Department of Fish and Game. 216-224.

- - - 2005. Unit 26A caribou management report. In: Brown, C., ed. Caribou management report of survey and inventory activities 1 July 2002-30 June 2004. Juneau: Alaska Department of Fish and Game. 246-268.

CARROLL, G.M., PARRETT, L.S., GEORGE, J.C., and YOKEL, D.A. 2005. Calving distribution of the Teshekpuk caribou herd, 1994-2003. Rangifer 16:27-35.

CHAN-McLEOD, A.C.A., WHITE, R.G., and RUSSELL, D.E. 1999. Comparative body composition strategies of breeding and nonbreeding female caribou. Canadian Journal of Zoology 77:1901- 1907.

CHAPIN, F.S., JOHNSON, D.A., and McKENDRICK, J.D. 1980. Seasonal movement of nutrients in plants of differing growth form in an Alaskan tundra ecosystem: Implications for herbivory. Journal of Ecology 68:189-209.

CRONIN, M.A., WHITLAW, H.A., and BALLARD, W.B. 2000. Northern oil fields and caribou. Wildlife Society Bulletin 28(4):919-922.

CRONIN, M.A., PATTON, J.C., BALMYSHEVA, N., and MacNEIL, M.D. 2003. Genetic variation in caribou and reindeer (Rangifer tarandus). Animal Genetics 34:33-41.

DAU, J.R. 1986. Distribution and behavior of barren-ground caribou in relation to weather and parasitic insects. MS Thesis, University of Alaska, Fairbanks.

- - . 2005. Units 21D, 22A, 22B, 22C, 22D, 22E, 23, 24, and 26A caribou management report. In: Brown, C., ed. Caribou management report of survey and inventory activities 1 July 2002-30 June 2004. Juneau: Alaska Department of Fish and Game. 177-218.

DAVIS, J.L., and VALKENBURG, P. 1979. Caribou distribution, population characteristics, mortality and response to disturbance in northwest Alaska. In: Lent, P.C., ed. Studies of selected wildlife and fish and their habitat on and adjacent to National Petroleum Reserve in Alaska (NPR-A), 1977-1978. Vol. 1, Work Group 3, Field Study 3. Anchorage: U.S. Department of the Interior. 13-52.

FANCY, S.G., PANK, L.F., DOUGLAS, D.C., CURBY, C.H., GARNER, G.W., AMSTRUP, S.C., and REGELIN, W.L. 1988. Satellite telemetry: A new tool for wildlife research and management. Resource Publication 172. Washington, D.C.: U.S. Department of the Interior, Fish and Wildlife Service.

FANCY, S.G., PANK, L.F., WHITTEN, K.R., and REGELIN, W.L. 1989. Seasonal movements of caribou in Arctic Alaska as determined by satellite. Canadian Journal of Zoology 67: 644-650.

FERGUSON, M.A.D., GAUTHIER, L., and MESSIER, F. 2001. Range shift and winter foraging ecology of a population of Arctic tundra caribou. Canadian Journal of Zoology 79: 746-758.

FINSTAD, G.L., BADER, H.R., and PRICHARD, A.K. 2002. Conflicts between reindeer herding and an expanding caribou herd in Alaska. Proceedings of the 10th Annual Arctic Ungulate Conference, Troms $\emptyset$, Norway. Rangifer Special Issue 13: $33-37$. 
FLECK, E.S., and GUNN, A. 1982. Characteristics of three barrenground caribou calving grounds in the Northwest Territories. Northwest Territories Wildlife Service Progress Report 7. 158 p.

FULLER, A.S., and GEORGE, J.C. 1997. Evaluation of subsistence harvest data from the North Slope Borough 1993 census for eight North Slope villages: for calendar year 1992. Available from the Department of Wildlife Management, Box 69, Barrow, Alaska 99723.

GERHART, K.L., WHITE, R.G., CAMERON, R.D., and RUSSELL, D.E. 1996. Body composition and nutrient reserves of Arctic caribou. Canadian Journal of Zoology 74:136-146.

GRIFFITH, B., DOUGLAS, D.C., WALSH, N.E., YOUNG, D.D., McCABE, T.R., RUSSELL, D.E., WHITE, R.G., CAMERON, R.D., and WHITTEN, K.R. 2002. The Porcupine caribou herd. In: Douglas, D.C., Reynolds, P.E., and Rhode, E.B., eds. Arctic coastal plain terrestrial wildlife research summaries. U.S. Geological Survey, Biological Resources Division, Biological Science Report USGS/BRD/BSR-2002-001. 8-37.

GUNN, A. 2000. Caribou calving grounds - dogma and diversity. Proceedings of the Eighth North American Caribou Workshop, Whitehorse, Yukon. Rangifer Special Issue 12:106.

GUNN, A., and MILLER, F. 1986. Traditional behaviour and fidelity to caribou calving grounds by barren-ground caribou. Proceedings of the Fourth Reindeer/Caribou Symposium, Whitehorse, Yukon. Rangifer Special Issue 1:151-157.

HINKES, M.T., COLLINS, G.H., VAN DAELE, L.J., KOVACH, S.D., ADERMAN, A.R., WOOLINGTON, J.D., and SEAVOY, R.J. 2005. Influence of population growth on caribou herd identity, calving ground fidelity, and behavior. Journal of Wildlife Management 69(3):1147-1162.

KNOTT, K.K., BARBOZA, P.S., BOWYER, R.T., and BLAKE, J.E. 2004. Nutritional development of feeding strategies in Arctic ruminants: Digestive morphometry of reindeer, Rangifer tarandus, and muskoxen, Ovibos moschatus. Zoology 107: $315-333$.

LENART, E.A. 2005. Units 26B\&C caribou management report. In: Brown, C., ed. Caribou management report of survey and inventory activities 1 July 2002-30 June 2004. Juneau: Alaska Department of Fish and Game. 269-292.

MÖRSCHEL, F.M. 1999. Use of climatic data to model the presence of oestrid flies in caribou herds. Journal of Wildlife Management 63:588-593.

MÖRSCHEL, F.M., and KLEIN, D.R. 1997. Effect of weather and parasitic insects on behavior and group dynamics of caribou of the Delta herd, Alaska. Canadian Journal of Zoology 75: 1659-1670.

NELLEMANN, C., and CAMERON, R.D. 1998. Cumulative impacts of an evolving oil- field complex on the distribution of calving caribou. Canadian Journal of Zoology 76:1425-1430.

NIXON, W.A.C. 1991. Group dynamics and behavior of the Porcupine caribou herd during the insect season. MS Thesis, University of Alaska, Fairbanks.

PARKER, K.L., BARBOZA, P.S., and STEPHENSON, T.R. 2005. Protein conservation in female caribou (Rangifer tarandus): Effects of decreasing diet quality during winter. Journal of Mammalogy 86:610-622.
PHILO, L.M., CARROLL, G.M., and YOKEL, D.A. 1993. Movements of caribou in the Teshekpuk Lake herd as determined by satellite tracking 1990-1993. Barrow, Alaska: North Slope Borough Department of Wildlife Management. $60 \mathrm{p}$.

POST, E., BOVING, P.S., PEDERSON, C., and MacARTHUR, M.A. 2003. Synchrony between caribou calving and plant phenology in depredated and non-depredated populations. Canadian Journal of Zoology 81:1709-1714.

PRICHARD, A.K., and MURPHY, S.M. 2004. Analyses and mapping of satellite telemetry data for the Teshekpuk caribou herd 1990-2002. Final report prepared for North Slope Borough Department of Wildlife Management, Alaska Department of Fish and Game, U.S. Bureau of Land Management. ABR, Inc. Box 80410, Fairbanks, Alaska.

PRICHARD, A.K., CARROLL, G.M., GEORGE, J.C., MURPHY, S.M., SMITH, M.D., SUYDAM, R.S., and YOKEL, D.A. 2003. Use of satellite telemetry to evaluate movements of caribou within subsistence hunting areas in northern Alaska. Rangifer 14:81-87.

REYNOLDS, P. 1982. Preliminary report on the status of the Teshekpuk caribou herd. Unpubl. manuscript. Available from U.S. Bureau of Land Management, Fairbanks District Office, 1150 University Avenue, Fairbanks, Alaska 99709.

RUSSELL, D.E., MARTELL, A.M., and NIXON, W.A.C. 1993. Range ecology of the Porcupine caribou herd in Canada. Rangifer Special Issue 8. $167 \mathrm{p}$.

SCHAEFER, J.A., BERGMAN, C.M., and LUTTICH, S.N. 2000. Site fidelity of female caribou at multiple spatial scales. Landscape Ecology 15:731-739.

SEAMAN, D.E., and POWELL, R.A. 1996. An evaluation of the accuracy of kernel density estimators for home range analysis. Ecology 77(7):2075-2085.

SILVA, J.B., ed. 1985. Habitat evaluation for Teshekpuk Lake Special Study Area study. Unpubl. manuscript. Available from U.S. Bureau of Land Management, Fairbanks District Office, 1150 University Avenue, Fairbanks, Alaska 99709.

SKOOG, R.O. 1968. Ecology of the caribou (Rangifer tarandus granti) in Alaska. PhD thesis, University of California, Berkeley, California. $699 \mathrm{p}$.

SPSS Inc. 2005. Version 14.0 statistical software. Chicago, Illinois: SPSS Inc.

STEPHENSON, R.O. 2005. Units 25A, 25B, 25D, and 26C caribou management report. In: Brown, C., ed. Caribou management report of survey and inventory activities 1 July 2002-30 June 2004. Juneau: Alaska Department of Fish and Game. 219-234.

VALKENBURG, P., and DAVIS, J.L. 1986. Calving distribution of Alaska's Steese-Fortymile caribou herd: A case of infidelity? Proceedings of the Fourth Reindeer/Caribou Symposium, Whitehorse, Yukon. Rangifer Special Issue 1:315-323.

WHITE, R.G. 1983. Foraging patterns and their multiplier effects on productivity of northern ungulates. Oikos 40:377-384.

- - - 1992. Nutrition in relation to season, lactation, and growth of north temperate deer. In: Brown, R.D., ed. The biology of deer. New York: Springer-Verlag. 407-417.

WOLFE, S.A. 2000. Habitat selection by calving caribou of the Central Arctic herd, 1980-95. MS thesis, University of Alaska Fairbanks, Fairbanks, Alaska. 